\title{
Nas fímbrias da liberdade agregados, índios, africanos livres e forros na Província de Minas Gerais (século XIX)*
}

\section{On the fringes of freedom}

\begin{abstract}
aggregates, Indians, free Africans and manumitted slaves in Minas Gerais in the nineteenth century ${ }^{* *}$
\end{abstract}

\author{
ANDRÉA LISLY GONÇALVES \\ Departamento de História \\ Universidade Federal de Ouro Preto \\ Rua do Seminário, sem número, Mariana, Minas Gerais \\ CEP. 30-535630 \\ alisly@terra.com.br
}

MARILEIDE LÁZARA CASSOLI MEYER Mestre em História pela Universidade Federal de Ouro Preto. Rua do Seminário, sem número, Mariana, Minas Gerais CEP. 30-535630 ml.meyer@uol.com.br

RESUMO O objetivo deste artigo é tratar alguns aspectos do trabalho compulsório, não escravo, nas Minas Gerais oitocentista. Através da abordagem do trabalho de indígenas, de recrutas, de africanos livres e de agregados pretendeu-se evidenciar o tema da vulnerabilidade e da instabilidade a que estavam sujeitos alguns homens livres pobres, em um contexto marcadamente escravista da Província: o Termo de Mariana, Comarca de Ouro Preto.

Palavras-chave Minas Gerais, escravidão, forros, agregados, africanos livres

* Artigo recebido em: 13/09/2010. Aprovado em: 03/06/2011.

** Esta pesquisa tem o apoio da FAPEMIG. 
ABSTRACT This paper aims at approaching some aspects of compulsory labor, not slave labor, in the nineteenth century Minas Gerais. Through the analysis of the work of indigenous, recruits, free Africans and aggregates it intends to evidence the issue of vulnerability and instability to which some free poor men were submitted in the context of a markedly slavery region: Term of Mariana, County of Ouro Preto.

Keywords Minas Gerais, slavery, manumitted slaves, aggregates, free Africans

\section{Introdução}

Em seu estudo sobre os africanos livres no Brasil, Beatriz Gallotti Mamigonian $^{1}$ faz referência às diversas formas de trabalho forçado de não escravos no Brasil imperial. Ombreados com escravos africanos ou crioulos nas lides agrárias e no desempenho de serviços urbanos, indígenas, forros, soldados, homens livres pobres e africanos apreendidos após a proibição do tráfico internacional de escravos irão constituir um grupo específico, embora heterogêneo, na história do trabalho no Brasil escravista, sendo destacados para a abertura de estradas em regiões isoladas de fronteira ou engajados em atividades extrativas nos sertões do país.

Concordando com o que há muito tempo vem sendo apontado pela historiografia brasileira, a autora ressalta que as tarefas mais duras, aquelas em que os senhores não estavam dispostos a empregar os seus cativos, foram desempenhadas, compulsoriamente ou não, por diversos estatutos de homens livres pobres. Mamigonian conclui seu artigo afirmando que, "em vez de uma gradual 'transição para o trabalho livre', o país experimentou a expansão do trabalho não-livre (...) e a expansão de outros arranjos de trabalho forçado". ${ }^{2}$

O objetivo deste artigo é tratar determinados aspectos assumidos pelo trabalho compulsório, não escravo, na província de Minas Gerais, ao longo do século XIX. Primeiramente, serão indicadas algumas situações em que o emprego da mão-de-obra indígena e de recrutas se mostrou essencial para a abertura de estradas nas regiões, antes proibidas, da fronteira ao leste da província. Em seguida, serão feitas breves considerações sobre o trabalho de galés que cumpriam pena na cadeia de Mariana. Posteriormente, serão abordadas histórias que se relacionam ao universo dos africanos livres. Por fim, e a partir de um documento exemplar, pretende-se reconstituir a

1 MAMIGONIAN, Beatriz Gallotti. Revisitando a "transição para o trabalho livre": a experiência dos africanos livres. In: FLORENTINO, Manolo. (org.) Tráfico, cativeiro e liberdade: Rio de Janeiro, séculos XVII-XIX. Rio de Janeiro: Civilização Brasileira, 2005, p.389-417.

2 MAMIGONIAN, Beatriz Gallotti. Revisitando a "transição para o trabalho livre", p.411. 
história de vida de um personagem, Antônio Francisco do Espírito Santo. Através desse estudo de caso, será tratado o tema da vulnerabilidade e da instabilidade a que estavam sujeitos alguns homens livres pobres, em um contexto marcadamente escravista da Província de Minas Gerais: o Termo de Mariana, Comarca de Ouro Preto.

\section{Trabalho compulsório em regiões de fronteira}

O exame da correspondência trocada entre Guido Thomas Marliére, nomeado pelo governador de Minas, no ano de 1813, diretor geral dos índios, atuando no Rio Pomba e no Presídio de São João Batista, e camaristas e autoridades militares da Comarca de Ouro Preto, revela vários aspectos da trama de interesses que uniam alguns senhores poderosos do Termo de Mariana à administração dos índios.

Dentre os missivistas, era com Manoel José Esteves Lima que Marliére mantinha uma correspondência mais ativa. Comandante vitalício das companhias de ordenança, Esteves Lima é apontado pela historiografia como homem de fortuna, um dos "senhores poderosos de Mariana", "homem muito influente na região, sendo grande proprietário de terras no Sertão do Casca (leste do Termo)". ${ }^{3}$

Em outubro de 1824, quando Manoel Esteves ainda era sargento mor, Marlière reconhece-lhe os serviços prestados na abertura da estrada do Itapemirim e acena com a possibilidade de recompensas, afirmando que, como diretor geral dos índios, não costumava "deixar em silêncio os merecimentos dos beneméritos, que me são subordinados". ${ }^{4}$ Em outra correspondência, datada de 12 de fevereiro de 1826, o administrador é obrigado a recusar o pedido de Manoel Esteves referente à transferência de um batalhão para a continuidade das obras da mesma estrada do Itapemirim, recomendando-Ihe que prossiga com a utilização do trabalho indígena, uma vez que o engajamento de soldados naquela tarefa estimulava a deserção. ${ }^{5}$

De que a forma de organização dos trabalhos de abertura da estrada do Itapemirim não gozava da melhor fama dão testemunho alguns que ali estiveram e que fizeram questão de comunicá-lo ao diretor geral do presídio: "A mim também se falou muito mal da Estrada". Porém, Marlière não se deixou impressionar e encoraja o sargento mor a dar prosseguimento na empresa: "Vá V.S. continuando os seus patrióticos serviços; (...) não tenho outro fim senão a civilização dos índios, e felicidade desta Província". ${ }^{6}$

\footnotetext{
3 ANDRADE, Francisco Eduardo. Poder local e herança colonial em Mariana: faces da Revolta do "Ano da Fumaça" (1833). In: Termo de Mariana: História e documentação. Mariana: UFOP, 1998, p.127-135.

4 Revista do Arquivo Público Mineiro, Belo Horizonte, v.10, p.502, 1905.

5 Revista do Arquivo Público Mineiro, Belo Horizonte, v.11, p.132, 1906

6 Revista do Arquivo Público Mineiro, v.11, p.146.
} 
Dentre as principais dificuldades apontadas, estavam o constante ataque de "bandoleiros e sequazes" que atingiam "aos índios, seu diretor e colonos", a submissão dos mesmos indígenas, vítimas de "pouco delicados opressores políticos", nas palavras do próprio Esteves Lima, além dos problemas de abastecimento das tropas que ali serviam:

E quanto ao fornecimento da Tropa ali destacada, não há mais, que mandar dizer ao Comandante da Divisão, que procure a tempo outro assentista, a fim de não ficarem os soldados com falta de mantimentos, que sirva de pretexto para desertarem. ${ }^{7}$

A situação não parecia fácil de remediar, como se pode ler, em outra correspondência, que se:

Não achar assentista para o destacamento da estrada de Itapemirim, e como seria inumanidade e manifesta injustiça deter ali 20 praças entregues aos horrores da fome, tomarei sobre mim a responsabilidade de os retirar daquele precipício, se V.S. não tomar um justo arbítrio para fazer cessar esta importante causa. ${ }^{8}$

Ao longo de todo o século XVIII, o temor das autoridades com o descaminho do ouro mantivera proibida aos colonos, com maior ou menor eficácia dos administradores, a região sobre a qual incidiam as demandas do capitão-mor Manuel José Esteves Lima, por ser uma via cuja paisagem natural e a presença indígena poderiam, ao mesmo tempo, dificultar e encobrir o contrabando.

Já no século seguinte, com a conjuntura de nova Nação, concorreu para a criação de uma infraestrutura essencial à integração do território o estímulo a que se devassasse esse sertão. O que se fez mobilizando trabalho compulsório de indígenas e recrutas e não pela utilização do braço escravo. No caso dos recrutas, a organização militar da qual faziam parte, sem querer aqui estabelecer distinções entre tropas de milícias e exército, dependia de uma estrutura não profissionalizada, com tendência a reproduzir relações clientelares típicas do contexto colonial. Nesse quadro, os subordinados não se vinculavam a um quadro hierárquico constituído por oficiais treinados, mas aos comandantes militares, com os quais entreteciam laços fora do âmbito militar. ${ }^{9}$

\footnotetext{
Revista do Arquivo Público Mineiro, v.11, p.132.

Carta do dia 28 de março de 1826. Revista do Arquivo Público Mineiro, v.11, p.150.

9 'O sistema de ordenanças padeceu sempre da 'tradução' local das ordens régias, (...) que, combinado à hierarquizada sociedade do Antigo Regime, tornou quase impossível o devido exercício disciplinar no interior das tropas, sempre sujeitas às redes clientelares capazes de 'flexibilizar' as demandas e os controles, fazendo pesar apenas sobre os não 'tutelados' os rigores da lei". HERMANN, Jacqueline. Um paraíso à parte: o movimento sebastianista do Rodeador e a conjuntura política pernambucana às vésperas da Independência (1818-1820). In: BICALHO, Maria Fernanda e FERLINI, Vera Lúcia do Amaral. (orgs.) Modos de governar: idéias e práticas políticas no Império português, séculos XVIII e XIX. São Paulo: Alameda, 2005, p.439.
} 
Na própria correspondência trocada entre Marlière e Manoel Esteves Lima, podem-se apreender traços da natureza ainda pouco profissionalizada da organização militar, como na passagem em que, ao referir-se às desordens provocadas por dois irmãos desertores, a garantia apontada para que os distúrbios não se repetissem é dada pela família dos milicianos, que assinaram termo comprometendo-se a não "voltarem aos lugares que serviam de teatro aos seus desaforos e a família me respondendo pelas transgressões". ${ }^{10} \mathrm{~A}$ intervenção das famílias parecia ser expediente comum na busca de assegurar a submissão de milicianos que tentavam se evadir, inclusive, do trabalho compulsório exigido para a abertura de estradas, como se verifica no trecho de uma carta de Marliére ao sargento mor: "Sinto tenha se evadido o principal chefe de tantos bandidos o desertor José de Lana: mas os seus parentes me dão esperanças de o tirar dali para voltar ao Regimento a que pertence". ${ }^{11}$

Tal como José de Lana, os dois irmãos transgressores citados na correspondência, muito provavelmente, pertenciam a famílias como a de Antônio Martins dos Santos, morador da Freguesia do Mártir São Manuel do Rio da Pomba e contemplado, no início dos oitocentos, com uma sesmaria "dentro das terras distribuídas para cultura dos índios", no "Córrego do Caeté, que deságua no ribeirão do braço do Turvo", região de fronteira. De acordo com o parecer expedido pela Câmara de Mariana para a concessão da sesmaria, o requerente era "homem pobre, casado, não tem escravos, porém tem 7 filhos machos e 7 fêmeas (...) e o suplicante não desmerece por ser homem bem instruído e de bom exemplo para a civilização dos mesmos índios". ${ }^{12}$

A possibilidade de recebimento de soldos, ainda que incertos, poderia representar uma renda monetária complementar ao trabalho na lavoura, sem dúvida a ocupação principal da maioria dos filhos do homem pobre Antônio Martins dos Santos. A contrapartida poderia ser a sujeição ao trabalho forçado na abertura e manutenção de estradas no leste da província, a outra face da realidade de famílias camponesas.

Quase dois anos mais tarde, a correspondência entre os dois militares mantém-se ativa e os dilemas continuam girando em torno do trabalho, via de regra forçado, principalmente para a conservação e a limpeza da estrada na região ao leste da província.

10 Revista do Arquivo Público Mineiro, v.11, p.158. Se ainda fossem necessários argumentos para se demonstrar a natureza violenta do processo de recrutamento para o exército, uma herança do período colonial que se prolonga pelo Império adentro, a seguinte passagem da mesma carta seria suficiente: "e se teimarem [os irmãos desertores], está em poder de V.S., como um dos principais empregados desse Termo, encarregado sobretudo da polícia e segurança pública, de os recrutar para o Exército para que são ótimos candidatos".

11 Revista do Arquivo Público Mineiro, v.11, p.158.

12 Parecer sobre a concessão de sesmaria (29 de março de 1801) e Parecer sobre a concessão de sesmaria (5 de dezembro de 1801). Arquivo Histórico da Câmara Municipal de Mariana (AHCMM). Acervo Complementar. Sesmarias. f.2. Transcrição: José Guilherme Ribeiro. Revisão: Ronaldo Polito. In: Termo de Mariana, p.212-213. 
Os rigores impostos a determinados segmentos de trabalhadores não cativos não se limitavam àqueles que serviam na construção e manutenção de estradas. No ano de 1874, a população da Comarca de Ouro Preto enfrentou o infortúnio de uma epidemia de varíola. Das providências tomadas em Mariana para mitigar os efeitos da epidemia constavam o traslado de algumas pessoas doentes e outras iniciativas que a documentação não dá, claramente, a entender.

Um registro relativo a providências tomadas para debelar os efeitos da epidemia revelam a que tipo de trabalhador tais tarefas estavam destinadas. Em setembro daquele ano, a Câmara Municipal remunerou os serviços prestados por galés nas tarefas, infelizmente não especificadas, relacionadas ao surto de varíola:

Recebi do senhor alferes Elias Augusto do Carmo, procurador da Câmara Municipal desta cidade, a quantia de quatro mil réis para distribuir pelos galés = Rafael Lopes, Francisco Dimenciano, Leonel Barbosa e Miguel Congo, a mil réis por cada um, de gratificação de serviços prestados no tempo de epidemia de varíolas. ${ }^{13}$

Dos três presos sujeitos a serviços forçados, apenas um, Miguel Congo, era escravo. Provavelmente, o $1 \$ 000$ que lhe coube, deve ter sido encaminhado, a título de jornal, ao seu senhor. Dois meses antes, Marco Antônio Ferreira recebeu a quantia de $\mathrm{R} \$ 10 \$ 000$ para a condução de uma vítima da varíola até Ouro Preto, não sabemos se para tratamento médico:

Recebi do llustríssimo senhor alferes Elias Augusto do Carmo, na qualidade de procurador da Câmara Municipal desta cidade, a quantia de $10 \$ 000$, provenientes de conduzir uma bexiguenta à cidade de Ouro Preto; e por não saber ler nem escrever, pedi ao senhor João Machado Pinheiro Costa, por mim, passar e assinar. ${ }^{14}$

O pagamento recebido por Marco Antônio Ferreira era módico, principalmente para um serviço tão insalubre. Assim, a disposição de realizá-lo e o fato de não saber ler nem escrever sugerem que o trabalho fora realizado por alguém de poucas posses, assumindo o papel para o qual os senhores relutavam em arriscar seus escravos. Mas, se o valor for contrastado com a modesta quantia recebida por cada um dos presos condenados a galés, revela-se a hierarquização dos mundos do trabalho, principalmente em uma sociedade na qual a compulsoriedade era a norma. Coube a cada um

13 Recibo por serviços prestados durante a epidemia de varíola. Transcrição de Valéria Mara da Silva. In: Termo de Mariana, p.172.

14 AHCMM. Recibo por condução de uma bexiguenta a Ouro Preto, 6 de julho de 1874. Transcrição de Valéria Mara da Silva. In: Termo de Mariana, p.170. 
exatamente a décima parte do valor recebido por Marco Antônio Ferreira, em empreitada que, supõe-se, fosse similar.

\section{Africanos livres}

Retomemos, aqui, as considerações feitas por Beatriz Gallotti sobre o segmento específico de trabalhadores constituído pelos africanos livres. De acordo com a autora, foi encaminhado do Rio de Janeiro para outras províncias 1/5 desses africanos capturados na África, mas tornados livres, após 1831, tão logo eram apreendidos nos portos brasileiros os navios em que fizeram a travessia. ${ }^{15}$ Não dispomos de dados quantitativos sobre a presença desses africanos em Minas Gerais. Mas localizamos, distantes no tempo, três documentos que, um de forma mais direta, os outros de forma mais tortuosa, permitem o desvendamento de aspectos relacionados ao universo dos africanos livres, tais como suas representações e implicações nos conflitos entre senhores e escravos.

Em fevereiro de 1850, João africano foi apreendido pelo inspetor de quarteirão do distrito de Vargem e enviado para a cadeia de Mariana. Levado diante do Juiz para interrogatório, João não pôde satisfazer a nenhuma das perguntas feitas pela autoridade por se achar "ainda inteiramente boçal". ${ }^{16}$ O principal ponto, o nome do "pretendido senhor e condutor de João", não foi, assim, esclarecido. Ainda que se mencione no documento a existência de um senhor e que, em determinadas passagens, ele seja referido como escravo, não aparece qualquer questionamento à sua condição de africano livre. A fim de "requerer o que de direito possa a bem da pessoa e interesse do dito Africano" foi instituído um curador, o Senhor José Joaquim Campos.

O estado de saúde de João inspirava cuidados. Coube ao juiz de órfãos, doutor Francisco de Paula da Silveira Lobo, providenciar-lhe tratamento médico. Em seguida, procedeu-se à avaliação do africano livre por louvadores ${ }^{17}$ nomeados exatamente para esse fim. Os louvados avaliaram os serviços em "12 mil réis/jornais; 24 mil réis. Valores do primeiro e segundo ano, a partir do terceiro e até sua emancipação deveria chegar a 36 mil réis". Apesar

15 O contingente de africanos livres no Brasil foi estimado por Robert Conrad em 11.000, número que o próprio autor reconhece ser inferior ao do contingente de fato existente no país ao longo do século XIX. Sua presença foi maior nos portos em que os navios foram apreendidos pela ação das autoridades britânicas, isoladas, ou em cooperação com as autoridades brasileiras. Os registros são mais abundantes para a Bahia, Maranhão, Santos e Pernambuco. CONRAD, Robert Edgard. Tumbeiros: o tráfico de escravos para o Brasil. São Paulo: Brasiliense, 1985, p.172. Das regiões portuárias foram distribuídos para outras províncias, como a do Paraná "a cargo do Barão de Antonina que estava envolvido em projetos de colonização com índios" e para a Colônia Militar de Itapura, no Mato Grosso. MAMIGONIAN, Beatriz Gallotti. Do que "o preto mina" é capaz: etnia e resistência entre africanos livres. Afro-Ásia, Salvador, n.24, p.81, 2000.

16 Todas as informações para a reconstituição do caso de João africano constam de documento do Arquivo da Casa Setecentista de Mariana (ACSM). Cód.401, auto 8778, I ofício, Ação cível de apreensão de escravo, 1850.

17 De acordo com o dicionário de Morais e Silva, louvado era o juiz escolhido pelas partes para resolver alguma controvérsia; árbitro. Dicionário da língua portuguesa. Lisboa: Typographia Lacerdina, 1813. http://www.ieb.usp. br/online/index.asp (acesso em 09 de agosto de 2010). O sentido permanece até hoje. 
de virem referidos como salários, os 12 mil réis anuais estabelecidos pelos árbitros, na verdade, era o valor a ser pago pelo arrematante ao curador dos africanos, válido para todo o Brasil, e deveria ser depositado no juízo da arrematação ou no Fundo dos Africanos Livres, pelos concessionários. No caso de Mariana, e certamente de outras regiões mais distantes do Rio de Janeiro, a quantia deveria ser recolhida à Câmara Municipal. Os acordos bilaterais assinados entre Brasil e Inglaterra estabeleciam que o objetivo de tal fundo era o de propiciar a repatriação dos africanos para seu continente de origem. ${ }^{18}$ Porém, na ação de liberdade que serve à presente reconstituição, não há menção a esse fim. De acordo com o documento, o arrematante deveria recolher a quantia até a data em que João "pudesse compreender seus deveres para com Deus, para com a sociedade e para consigo mesmo".

Apesar de ser bastante variada a gama de serviços nos quais era comum encontrarem-se empregados os africanos livres - tarefas domésticas, mineração, serviços urbanos, atividade a ganho - e de os contratadores poderem reaver em menos de um mês a quantia depositada nos cofres públicos por um ano inteiro de aluguel, ${ }^{19} \mathrm{O}$ trabalho do africano João não foi arrematado dessa vez. Talvez, tenha pesado para isso o seu estado precário de saúde e, também, quem sabe, a sua disposição para a fuga.

Não demorou muito, porém, e procedida nova louvação, os serviços do africano foram arrematados. Afinal, o atrativo de auferir um lucro mais de dez vezes superior ao capital investido não era algo desprezível, sobretudo em uma conjuntura em que a cessação do tráfico internacional de escravos projetava a elevação dos preços dos cativos.

João africano permaneceu, inicialmente, com seu novo senhor, ${ }^{20} \mathrm{O}$ comerciante Antônio Vicente Ferreira de Oliveira, pelo período que se estendeu de 04 de março a 7 de abril de 1850. Nesse intervalo, de acordo com as palavras de Antônio Vicente, o negociante cuidou para que João se restabelecesse do seu "mau estado de saúde e brutalidade". Só se pode especular, uma vez que a documentação não o menciona, que as precárias condições de saúde de João seriam consequência de maus tratos aplicados por seu senhor anterior. Afinal, eram recorrentes em outras províncias as queixas de castigos violentos partilhados por escravos e africanos livres. ${ }^{21}$

18 RODRIGUES, Jaime. Ferro, trabalho e conflito: os africanos livres na fábrica de Ipanema. História Social, Campinas, n.4/5, p.30, 1997/1998.

19 "Era uma concessão valiosa, já que os concessionários pagavam ao Fundo dos Africanos Livres a soma de $12 \$ 000$ por ano... pelos serviços dos africanos, mas podiam ganhar a mesma quantia em apenas um mês se trabalhassem ao ganho". MAMIGONIAN, Beatriz Gallotti. Do que "o preto mina" é capaz, p.71.

20 É curioso notar que a palavra tutor, com a qual a legislação procurava designar o arrematante, não aparece uma vez sequer no documento.

21 É o caso do escravo Desidério, apreendido na Bahia e que, durante dezenove anos, foi obrigado a prestar os mais "descomedidos serviços" e a submeter-se "aos mais injustos castigos". MAMIGONIAN, Beatriz Gallotti. Do que "o preto mina" é capaz, p.88. A passagem, comum em outros registros, assinala não apenas a indistinção entre escravos e africanos livres no que diz respeito a sevícias, facilitadas por servirem lado a lado com cativos, mas 
Na noite de 07 para 08 de abril, João evadiu-se novamente, sendo encontrado somente em janeiro de 1851, em Caeté, Comarca de Sabará, quando foi restituído ao arrematante.

Daquela data em diante, o africano livre serviu a Antônio Vicente por cerca de oito anos, ainda que não sem interrupções. As informações esparsas sobre o dia a dia de João provém, sobretudo, das passagens da ação de liberdade em que o comerciante tenta justificar as razões de não ter recolhido aos cofres públicos, ao final de quase uma década, a quantia correspondente à arrematação do africano livre. João era alugado para prestar serviços a terceiros. Foi na condição de servente em casa de Luis Ricardo Leão que ele sofreu uma queda "da qual ficou em estado de quase morto". O acidente foi tão grave que a vítima não pode "prestar serviço algum durante o espaço de 9 meses e 10 dias", só retornado às atividades no dia 11 de fevereiro de 1852. A exposição do africano livre a condições tão precárias de trabalho reforça o que foi dito anteriormente sobre a disposição de homens livres abonados de pouparem seus escravos das tarefas mais perigosas. ${ }^{22}$

Dentre as despesas relacionadas pelo arrematador, constava o pagamento feito a Francisco de Paula Lima, ao longo dos oito anos, pelo fornecimento de roupas ao africano livre, no valor de $189 \$ 700$ réis. A quantia de $75 \$ 7000$ foi a remuneração auferida por Raimundo Ferreira Franco que procurou e capturou João, trazendo-o de volta de Caeté, para onde tinha se evadido, para Mariana. Cerca de um terço desse valor foi despendido nas despesas para o tratamento médico de João.

Acertadas as contas e deduzidas as despesas com as moléstias e a fuga, o arrematante dispensou os serviços de João, para o qual foi nomeado um curador, o advogado Coronel Paulo Ramos, com a função de, junto à justiça, dar novo destino ao africano livre.

O futuro de João passou a depender, então, da apresentação de evidências de que o período de prestação de serviços alcançara o seu objetivo. Para tanto, seria necessária a avaliação a respeito de suas "qualidades ou sentimentos" e, se ao longo dos oito anos, comparativamente ao momento em que chegara à cidade, em fevereiro de 1850, ele se tornara adaptável.

Tanto o Juiz responsável pelo africano, quanto o curador não tiveram dúvidas de que a pessoa mais indicada para prestar tal testemunho seria o comerciante que arrematara os serviços de João. O depoimento de Antônio Vicente Ferreira de Oliveira foi, de fato, esclarecedor:

também a noção de castigo justo, uma prerrogativa reivindicada, sobretudo, por noções de cativeiro baseadas em práticas paternalistas.

22 "A sorte dos africanos livres era pior que a dos escravos, afirmou Burlamaque, porque o primeiro custava a seu senhor apenas 18 mil-réis, e que importância tinha se africanos obtido por um preço tão baixo morresse de fome ou sucumbisse ao excesso de trabalho?". CONRAD, Robert Edgard. Tumbeiros, p.179. 
Conquanto tenha o mesmo a pronúncia algum tanto ininteligível, todavia Ihe parece estar em estado de ser julgado emancipado, por achar-se bastante ladino, embora pareça à primeira vista o contrário, conhecendo seus deveres para com Deus e para com a sociedade, e já está batizado.

O registro da anuência do arrematante em relação à liberdade de João é revelador das práticas paternalistas da sociedade oitocentista brasileira, uma vez que, "embora sofra (...) com algum prejuízo, como deseja beneficiar o mesmo Africano não se opõe [à emancipação]".

O curador de João evocou a lei de número 1303, de 28 de dezembro de 1853, que estabelecia que seriam emancipados, desde que o requeressem, todos os africanos que tivessem prestado serviços a particulares por quatorze anos ou mais. Estes deveriam, porém, residir em local designado pelo Governo e tomar ocupação ou serviço mediante um salário. No caso de João, foi sugerido que ele fosse enviado para o Jardim Botânico. No universo dos africanos livres, mais uma vez, e de forma semelhante ao que ocorria a muitos forros e homens pobres, liberdade - no caso, emancipação -, não se confundia com autonomia.

Se não restam dúvidas de que João era um africano livre, menos óbvia era a situação de outro João e de seu parceiro, Antônio Avellar. Suas histórias se inserem no contexto da crise da escravidão, acentuada a partir da década de 1870. Naquele período, registraram-se, nas diversas províncias, um número maior de ações de liberdade movidas com base no argumento de cativeiro ilegal dos escravos introduzidos após a proibição do tráfico internacional, em 1831.23 O que parece particularizar o caso dos escravos João e Antônio Avellar é que, por muito pouco, eles não tiveram o destino de João africano, que se buscou reconstituir logo acima.

No ano de 1876, então morador em Mariana, João africano, através de seu curador, moveu uma ação de liberdade contra seu senhor. O processo se baseava na alegação de que o navio no qual fora trazido da África até o porto do Rio de Janeiro havia sido perseguido por um "vigilante cruzeiro britânico" e, após a ação particularmente enérgica da polícia brasileira (era o ano de 1851), os passageiros "entregues para serem educados ao coronel Custódio". ${ }^{24}$

Não temos informação sobre o tutor desses africanos, o coronel Custódio, mas já tivemos oportunidade de abordar, mais acima, o que estava implícito em tal aprendizado: a prestação de serviços, fosse sob tutela direta do Estado, fosse de particulares, por um prazo que, ao talante da lei,

23 Sabe-se que a lei de 1831 não teve efeitos práticos sobre o ingresso de africanos escravizados no Brasil. Calculase que entre aquele ano e o de 1850 cerca de 700.000 africanos foram desembarcados ilegalmente no país.

24 Todas as informações para a reconstituição do caso referem-se a: ACSM. Cód.258, auto 637, II Ofício. Ação de liberdade, ano1875. 
poderia coincidir com a vida do africano. ${ }^{25}$ No documento, estão registrados oito africanos livres que cruzaram o Atlântico com João e ficaram sob a tutela do coronel Custódio: Carlos, pedreiro de ofício, Joaquim Antônio, Calisto Congo, Adão Moçambique, Trajano da Costa e Hedelviges, "todos companheiros e patrícios do Suplicante [João Africano]".

Em 1875, ano da ação movida por João Africano e que coincide com o período de 14 anos estabelecido pela lei 1303, de 28 de dezembro de 1853, que determinava a emancipação definitiva dos africanos livres que tivessem servido a particulares "achavam-se [todos] no gozo de suas liberdades".

João e outros irmãos de travessia, porém, tiveram outra sorte. Durante o desembarque, cientes da efetiva intervenção dos navios ingleses e da determinação da polícia brasileira, o comandante traficante:

Resolveu bordejar no alto mar e ir desembarcando pouco a pouco os infelizes africanos. Acontece que por desgraça do Suplicante [João africano] foi ele o primeiro e alguns mais que fizeram a carga de um pequeno vapor, que são e salvo aportou-se, quando este voltou já tinha sido apreendido o navio e todos os africanos restantes. ${ }^{26}$

Em seguida, João e seus companheiros Casemiro, Manoel Congo, Antonio Avellar e José Adolpho foram "escondidos no Rio de Janeiro" e seguiram "de noite para Minas, e fizeram sempre de noite todas as viagens até a casa do finado Luiz Carvalho, que os comprou no Rio de Janeiro".

Passado quase um quarto de século, talvez estimulado pela emancipação dos africanos livres, seus malungos, com os quais certamente convivia, uma vez que moravam em Mariana e Ouro Preto, João resolve mover a ação contra seu senhor. Conforme previsto nesses casos, o africano foi depositado na casa de seu curador. Sua confiança de que a decisão da justiça lhe seria favorável não era irrestrita. Tanto é assim que João evadiu-se para Santa Bárbara, pretendendo, dali, ganhar os sertões da Bahia. Chama atenção o disfarce que esse escravo ladino assumiu para seguir com seus planos: em Santa Bárbara fazia passar-se por Barnabé.

Capturado e trazido de volta a Mariana, foi depositado na prisão, um dos principais locais para onde, desde os anos iniciais de repressão ao tráfico negreiro, eram remetidos, nas diversas regiões do Brasil, os africanos livres. ${ }^{27} \mathrm{~A}$ primeira providência do novo curador nomeado para representá-

25 MAMIGONIAN, Beatriz Gallotti. Do que "o preto mina" é capaz, p.392.

26 A situação narrada nos autos não era um fato isolado. O brigue Dois de Fevereiro, proveniente de Benguela, com 500 pessoas, em 1841, teve 195 cativos desembarcados na costa do Rio de Janeiro antes de ser abordado pelo cruzador Britânico Fawn. MAMIGONIAN, Beatriz Gallotti. José e Francisco Moçambique, marinheiros das rotas atlânticas: notas sobre a reconstituição de trajetórias da era da abolição. Topoi, v.11, n.20, p.75, Janeiro/junho 2010.

27 "Para muitos, a primeira parada no Rio era a Casa de Correção, cadeia da cidade para criminosos, e seu confinamento aí era sempre desagradável e prolongado, a prisão servindo às vezes como residência permanente para os africanos livres que trabalhavam nessa cidade". CONRAD, Robert. Tumbeiros, p.176. 
lo, o advogado Egydio Antônio do Espírito Santo Saragoça, foi a de tentar retirá-lo da cadeia pública. Seus argumentos a favor da retirada de João da casa de correção para ser depositado em casa de particulares evidenciam a crise de legitimidade da escravidão nos seus anos finais. Saragoça baseia sua representação questionando um dos principais pilares formais da instituição ao longo do oitocentos, o da inviolabilidade da propriedade privada senhorial:

No tempo em que a escravidão era mantida como um direito, e em que o escravo era considerado coisa, sem persona livre alguma era ele quando tratava do seu direito de liberdade manutenido na posse de três dias na semana em que gozava de sua liberdade para poder intentar e defender seus direitos em Juízo, como ensina Phebo em seus arestos, entretanto no tempo presente quando se considera a escravidão como um vício, como um veneno, para o que se descobriu antídoto, é agora que se encarcera para a garantia (...) a título de depósito um infeliz libertando durante a lide. E não será isto um atentado entre os direitos do Libertando que confiado na promessa da Lei veio a Juízo [e] ficou mais coagido do que antes.

Infelizmente, pela documentação encontrada, não se conhece o desfecho da ação. O que não quer dizer que a história desse grupo de africanos, trazidos ilegalmente para o Brasil, termine com a demanda de João africano.

Em 1883, o caso é retomado, agora envolvendo Antônio Avellar, que teria vindo no mesmo navio apreendido no ano de 1851 e que estava no pequeno vapor em que se encontrava João africano, conforme assinalado. A história, porém, tem um desfecho inesperado. Depois de o curador ter entrado com a ação de liberdade, nos mesmos termos que a do africano João, o próprio Antônio desautoriza a iniciativa:

Constando-Ihe que o cidadão José Francisco Couto apresentara a V.S. um requerimento assinado a rogo do suplicante pedindo depósito de sua pessoa, para intentar uma ação de liberdade, sob o fundamento de que é o suplicante importado posteriormente à lei de 1831, vem declarar que nada pediu ao referido cidadão, que a seu rogo assinou. Por quanto reconhece que de fato é cativo, visto como tem a idade de 56 anos e como não quer prestar a vinganças alheias, faz a presente declaração.

A situação pareceu inusitada às próprias autoridades encarregadas do caso que decidiram, então, interrogar Antônio Avellar, a fim de esclarecer os fatos. Depois de relatar as memórias que guardava de sua infância no Congo e de sua família, pai, mãe e sete irmãos, sendo ele o do meio, Antônio afirmou ter sido embarcado em um navio para o Brasil, juntamente com os seus irmãos mais velhos.

Os esforços das autoridades judiciais marianenses deram-se, então, no sentido de estabelecer a antiguidade em que tais fatos aconteceram. Para tanto, parecia decisiva a resposta ao tipo de navio no qual fora feita 
a travessia, se a vapor ou a vela e se a embarcação tinha sido perseguida por algum navio estrangeiro. Consta nos autos que Antônio respondeu que "se recorda ter vindo em navio de vela" e que "nunca foram perseguidos por embarcação alguma". Perguntado, ainda, pela razão que o levava a presumir que fosse um africano livre, teria respondido que "nunca disse coisa nenhuma porque reconhece ser escravo".

Diante do exposto, não coube alternativa ao curador senão deixar de apresentar a ação em juízo, concluindo que o exame dos autos revelava que Antonio "foi trazido para esse país no ano de 1827 quando ainda era permitida a introdução de africanos como escravos".

Há que acrescentar que a firme disposição de Antônio de se reconhecer como escravo e a aceitação de sua versão desmontam toda a argumentação apresentada por João em sua demanda. Chama a atenção, também, a aceitação por parte das autoridades encarregadas da ação, como ponto pacífico, de que os navios que ingressaram no Brasil no final da década de vinte não estavam sujeitos a sanções do tráfico ilegal.

Os acordos entre Inglaterra e Brasil para a proibição do infame comércio, como se sabe, datam da vinda da Família Real para a América. Tanto é assim que já se registra a presença de africanos livres no Reino Unido e Portugal e Algarves desde o ano de 1818. ${ }^{28}$ Depois disso, as pressões se intensificam como parte das exigências da Inglaterra para o reconhecimento da nossa independência até culminarem com a assinatura da lei de 1831.

É bem verdade que os acordos que permitiam à Inglaterra perseguir os navios que traziam africanos escravizados para o Brasil, a princípio, restringiam-se àqueles provenientes das áreas ao norte do Equador. João e Antônio são referidos nos documentos pela condição vaga de africanos. Os escrivães, porém, foram mais específicos ao assinalarem a origem de outros de seus companheiros, identificados como congo e moçambique, o que nos leva a presumir que, também, João e Antônio teriam vindo ou da área central ou oriental da África. Mas tais aspectos não passariam de detalhes em um contexto no qual a deslegitimação da instituição da escravidão era um fato socialmente abrangente. A perda crescente de apoio à instituição, porém, não evitava que demandas judiciais envolvendo africanos, escravos ou livres, se decidissem em favor de proprietários, prestando a "alimentar vinganças alheias", como no caso aqui abordado.

\section{Só a ela por prêmio pretendia}

A história de Antônio Francisco do Espírito Santo, reconstituída a partir de uma ação de liberdade, também é ilustrativa das muitas facetas que

28 Sobre o assunto ver CONRAD, Robert. Tumbeiros, p.66-89. Em especial o capítulo "Tráfico ilegal", 
marcaram a instabilidade da condição dos trabalhadores não escravos no Brasil oitocentista e na província de Minas Gerais, em particular.

No ano de 1819, por ocasião da morte de sua mãe, Antônio Francisco do Espírito Santo mudou-se, na condição de agregado, para a propriedade do Alferes Antônio Moutinho Esteves, situada em Jequeri, Freguesia do Anta, termo de Mariana, Comarca de Ouro Preto. ${ }^{29}$ Espírito Santo seguia o mesmo padrão da família da qual provinha. Seu pai, homem livre, também era agregado de um fazendeiro cujas terras situavam-se próximas a Ponte Nova. As informações que temos sobre a condição de Espírito Santo provêm, indiretamente, do registro da qualidade de uma das testemunhas, o ex-escravo e agregado Marciliano Pereira Moutinho, que era seu primo, e da sua certificação de casamento, na qual consta que ele era misto. Seu parentesco com Marciliano e a indicação de misto não deixam dúvidas de que se tratava de um mestiço.

Porém, não é na condição de mestiço ou de pardo que Espírito Santo é identificado pelas pessoas chamadas a testemunhar no processo por ele instaurado, no ano de 1858. Recorrente é a afirmação de advogados e testemunhas de que se tratava de homem rústico: "rústico e ignorante, mas de boa fé"; "rústico, sincero, verdadeiro e de boa fé".

Não podemos afirmar se a designação rústico, àquela altura, ainda guardava uma relação estrita com a sua definição no direito português. Entretanto, se considerarmos o peso que as ordenações do reino possuíam em um contexto no qual o direito costumeiro definia boa parte das questões no âmbito da justiça, ${ }^{30}$ pode ser que o recurso ao termo, que reportava a um perfil de morador como o agregado Antônio do Espírito Santo, estivesse associada à sua definição pretérita.

Na literatura clássica do direito comum, eram considerados rústicos os que "vivem fora das cidades ou das terras importantes". ${ }^{31}$ De acordo com os tratadistas modernos, a ignorância e a rudeza justificavam o estatuto especial dos rústicos, pessoas cuja "natureza parecia ter compensado a

29 As informações que permitiram a reconstituição dos fatos relatados encontram-se em: ACSM. Cód.386, auto 8436, I Ofício. Ação de liberdade, 1858 e ACSM. Cód.442, auto 9152, I Ofício. Ação de liberdade, ano 1858. Procuramos distinguir os elementos que, na ação cível, dizem mais respeito à memória dos sujeitos, por se reportarem aos anos 1820 e 1830, daqueles que guardam uma relação mais imediata com os episódios contemporâneos à década de 1850. Para tanto, voltamos a atenção ao estabelecimento do contexto social e econômico do Termo, nas décadas iniciais do oitocentos, para nele traçar o perfil dos personagens. Além disso, não nos passou despercebido que alguns argumentos podem ter sido realçados devido à conjuntura pós-tráfico internacional de escravos que começava a alterar a sensibilidade da sociedade da época em relação à escravidão. Vale lembrar que se trata de um momento no qual a concentração da propriedade cativa diminuía a base social de apoio à instituição.

30 A análise das ações cíveis envolvendo escravos, referentes ao Termo de Mariana, entre 1850-1888, aponta o uso recorrente às Ordenações Filipinas, Livros 3 e 4, nas demandas envolvendo escravos e seus senhores. Mesmo com o avanço da legislação referente à escravidão, no decorrer do século XIX, o recurso às Ordenações não desapareceu dos processos judiciais. Tornou-se contudo subutilizado, marcadamente após as Leis de 1871 e de 1885, que uniformizaram e normatizaram os procedimentos relativos à alforria dos cativos, entre outros. MEYER, Marileide Lázara Cassoli. Arranjos de vida: direito e relações entre senhores e escravos. Termo de Mariana, 18501888. Mariana: UFOP, p.96, 2010. (História, Dissertação de mestrado).

31 HESPANHA, António Manuel. Imbecilitas: as bem-aventuranças da inferioridade nas sociedades de Antigo Regime. Belo Horizonte: Ed.UFMG, 2008, p.109. 
debilidade do entendimento com a robustez física, como que denotando aquela especialização que os fazia mais próprios para servir, com o trabalho físico, do que para governar, com o engenho intelectual". ${ }^{32}$ Na formação do império português, aos rústicos do interior, ou seja, aos habitantes das áreas despovoadas de Portugal, irão corresponder "estes rústicos do ultramar que são os negros e os ameríndios". ${ }^{33}$ No caso que nos ocupa, rústico pode ser associado à figura do agregado.

Segundo Leandro Braga Andrade, os agregados eram, em boa medida, pessoas pobres, homens, na sua maioria, "dependentes dos grandes proprietários que trabalhavam no funcionamento da unidade produtiva, ou seja, em geral estavam ligados a serviços manuais, transporte e administração das fazendas". ${ }^{34}$ Os agregados somavam $12 \%$ da população livre da Freguesia do Furquim que, à época em que Antônio do Espírito Santo se instalou na fazenda de Moutinho, compreendia os curatos de Ponte Nova, Ubá, Conceição do Gualaxo do Norte e Conceição do Turvo. As fazendas com maior número de escravos abrigavam uma proporção maior de agregados, cerca de $29 \%$, o que sugere tratar-se de mão-de-obra complementar ao trabalho cativo. ${ }^{35}$

Retomando a história de vida do agregado Antônio do Espírito Santo, sabemos que, ainda no ano de 1819, conheceu Eugênia, escrava de Moutinho. As informações sobre a origem de Eugênia são dúbias. Na ação cível de liberdade consultada, ela aparece ora como crioula, ora como africana. Dois anos mais tarde, em 1821, o casal dirigia-se para Ponte Nova a fim de realizar suas núpcias, no que fora acompanhado pelo senhor da escrava. Ficou acordado que o padre que realizaria a cerimônia, o reverendo Tadim, também redigiria o contrato que tratava da alforria da cativa. Espírito Santo comprometia-se a prestar doze anos de serviço gratuito, em troca da liberdade de Eugênia, auxiliando Moutinho não apenas nas tarefas agrícolas, mas também na condução de tropa, nos serviços de carpintaria e em atividades de coleta, "internando-se pelo mato na cata de poaia".

O lucrativo comércio da poaia ou ipecacuanha, raiz usada como remédio contra tosse, vomitivo e expectorante, foi responsável pela afirmação de vários povoados em Minas Gerais, como foi o caso de São Batista do Presídio, que pertencia ao Termo de Mariana. De acordo com Sérgio da

32 HESPANHA, António Manuel. Imbecilitas, p.140.

33 HESPANHA, António Manuel. Imbecilitas, p.140. As acepções do termo rústico não sofrem grande variação, por exemplo, entre a definição encontrada em Bluteau, aquele "homem do campo", para o qual a "rusticidade serve de ignorância" e a registrada por Morais, na edição de 1813 do seu dicionário, "camponês", "homem rústico", "inurbano", "descortês". BLUTEAU, Raphael. Dicionário Portuguez e Latino. Coimbra: 1712-1721. In: http://www.ieb. usp.br/online/index.asp. (acesso em 09 de agosto de 2010). Dicionário da língua portuguesa. Lisboa: Typographia Lacerdina, 1813. http://www.ieb.usp.br/online/index.asp. (acesso em 09 de agosto de 2010).

34 ANDRADE, Leandro Braga. O ouro que escorre do alambique. Riqueza, hierarquia social e propriedade de engenhos em Minas Gerais. O caso da Freguesia de Furquim. 1821-1850. Anais do XIII Seminário sobre a economia mineira. Diamantina: Cedeplar, 2008, p.8.

35 ANDRADE, Leandro Braga. O ouro que escorre do alambique, p.8. 
Mata, a criação de um quartel naquele local, em junho de 1789, com 60 soldados, deveu-se à necessidade de controle daquela atividade:

Em 1824 o arraial tinha nada menos que 360 casas. Criavam-se suínos, plantavase milho, feijão, café e cana-de-acúcar. O comércio da ipecacuanha mantinha-se intenso. Os índios extraíam a raiz para vendê-la pelo preço de 6 patacas (2.000 réis) ao quilo. ${ }^{36}$

Foram muitos os fazendeiros que se enriqueceram com a comercialização da planta medicinal. Em fins do século XVIII, dom Domingos da Encarnação Pontevel, bispo de Mariana entre 1779 e 1793, denunciava que o produto era obtido à "custa de braços daqueles mesmos que engodam em alguns pedaços de lençóis, chitas a troco de imensos quintais de poaia extraída pelos mesmos [índios] que depois de tantos suores ficam iludidos com algumas porções de aguardentes", enquanto "os diretores e mais comerciantes" ocupavam o lugar de "bem ricos e afazendados". ${ }^{37}$

No século XIX, entre os anos 1818 e 1832, a poaia constava entre os principais produtos exportados por Minas Gerais para o Rio de Janeiro, juntamente com o açúcar, a aguardente, os panos e o gado. A Comarca de Ouro Preto se destacava nesse comércio. ${ }^{38} \mathrm{~A}$ mão-de-obra utilizada na sua extração, conforme referido, era preponderantemente indígena, mobilizada através do serviço forçado, o que, de alguma forma, dizia respeito ao mundo do trabalho de Espírito Santo, a cuja história, mais uma vez, retornamos. Na falta de maiores informações sobre as posses do alferes Antônio Moutinho Esteves - os dados de seu domicílio não aparecem nas listas nominativas de habitantes disponíveis à consulta - podemos creditar, pelo menos em parte, ao comércio da poaia a condição de homem poderoso, ao qual não faltarão recursos, como é referido na documentação.

As dificuldades que Espírito Santo iria enfrentar mais tarde já se encontravam anunciadas nas advertências feitas por seus companheiros, que temiam por ver-Ihe os filhos castigados no terreiro. A tais advertências o agregado quase sempre respondia que "paciência que os cães também tinham filhos".

De fato, desde o acordo estabelecido por ocasião da cerimônia de casamento, processou-se a certa inversão no tratamento dispensado por Moutinho a seu arrendatário, situação que aparece descrita no relato de várias testemunhas.

Além da sobrecarga de trabalho exigida pelo pagamento da alforria de Eugênia, Moutinho não se privava de infligir castigos físicos a Espírito Santo,

36 MATA, Sérgio Ricardo. Catolicismo popular, espaço e proto-urbanização em Minas Gerais, Brasil. Séculos XVIII-XIX. Colônia: Universidade de Colônia, 2002, p.183. (História, Tese de doutorado).

37 Arquivo da Câmara Municipal de Mariana. Epistolário dos Governos Episcopais, D. Domingos Pontevel (17791793). Apud: RESENDE, Maria Leônia Chaves de. Gentios brasílicos: Índios coloniais em Minas Gerais setecentista. Campinas: Unicamp, 2002, capítulo 2. (História, Tese de doutorado).

38 CHAVES, Cláudia Maria das Graças. Melhoramentos no Brazil: integração e mercados na América Portuguesa (1780-1822). Niterói: UFF, 2001, p.268-282. (História, Tese de doutorado). 
tratando-o do mesmo modo que os demais escravos como o próprio alferes declarara, num lapso que evidenciava a natureza da relação à qual ficara submetido o homem livre Antônio do Espírito Santo. E mais:

Obrigava-o rigorosamente a mais serviços do que os seus próprios escravos dizendo que sua mulher era forra e ele Autor seu cativo. E não obstante ser homem livre cumpriu sempre pontualmente a sua obrigação não escapou de sofrer por algumas vezes, maus tratos chegando o Réu a quebrar-lhe a cabeça.

Em contrapartida à reclamação do autor, o réu, Alferes Antonio Moutinho Esteves, insistia que firmara o contrato por pura condescendência, pois Espírito Santo era pouco trabalhador e seu serviço de má qualidade e que, mesmo trabalhando o dobro do tempo, estipulado em doze anos, não saldaria o valor da escrava "moça robusta, e de qualidades e que muito prometia para o futuro".

Ao aceitar o contrato estabelecido, Antonio Francisco perdia o atributo de autonomia que qualificava o estado de liberdade. Muito embora a relação senhor/escravo não fosse uma relação contratual, a perda da autonomia era compreendida como uma equiparação ao estado de submissão, logo, de não liberdade, ou seja, o estado de cativo.

Para o Alferes, a imagem de Antonio Francisco como trabalhador remetia aos argumentos que justificavam a necessidade de disciplinamento e controle da mão-de-obra livre, a saber, a pouca disposição ao trabalho e a má qualidade das tarefas desempenhadas. O tratamento conferido pelo Alferes a Antonio Francisco, sobretudo os castigos físicos que the eram aplicados, adquire sentido, dentro dessa ótica, na medida em que as punições recebidas pelo agregado correspondiam àquelas dispensadas a um escravo que não cumprisse suas obrigações de maneira satisfatória.

Disciplina e controle permeavam as relações de trabalho escravistas e se estenderiam ao trabalhador livre à medida que as dificuldades de obtenção de mão-de-obra cativa pós 1850, com a cessação definitiva do tráfico internacional de escravos, ${ }^{39}$ se intensificavam e a realidade da abolição se tornava cada vez mais concreta, no avançar do século XIX.40

39 Acerca das questões políticas envolvendo a aprovação da Lei contra o tráfico internacional de escravos em 1831 ver: BEIGUELMAN, Paula. O encaminhamento político do problema da escravidão no Império. In: HOLANDA, Sérgio Buarque de. (org.) História geral da Civilização Brasileira. São Paulo: Difel, 1976, v.3, p.190. Vale ressaltar que a autora aponta uma série de mecanismos jurídicos que possibilitavam burlar a lei. Tal fator, somado ao mutismo da sociedade acerca da questão escravista no período, teria contribuído para que a primeira lei contra o tráfico internacional de escravos se tornasse letra morta. Em CARVALHO, José Murilo de. A construção da Ordem: a elite política imperial; CARVALHO, José Murilo de. Teatro de sombras: a política imperial. Rio de Janeiro: Civilização Brasileira, 2008, p.302-303; o autor aponta os fatores políticos, econômicos e sociais que teriam levado ao sucesso da proibição do tráfico internacional de escravos em 1850. Entre estes fatores, podemos destacar a condenação moral ao tráfico e à escravidão, a efetivação da proposta da lei de terras e colonização, feita ainda em 1842, e o reconhecimento dos efeitos negativos que as pressões e bloqueios ingleses teriam para a soberania do país. Além disso, a aprovação da Lei de 1850 colocou em pauta a dependência da "saúde da lavoura" em relação ao braço cativo e a necessidade de importação de mão-de-obra imigrante para salvaguardar os interesses dos proprietários. Dessa forma, imbricavam-se o processo de consolidação de um poder político centralizado, a preservação da soberania nacional e o encaminhamento da questão da mão-de-obra, fosse ela escrava, imigrante ou o trabalhador livre nacional.

40 A dinâmica de controle, fixação e educação da mão-de-obra foi reforçada no decorrer do século XIX através de 
Conhecemos o desfecho da ação movida por Espírito Santo, pelo menos no âmbito da justiça da província. Os argumentos pareceram suficientemente fortes para que, na primeira sentença proferida, o que ocorreu a 23 de julho de 1861, o juiz municipal de órfãos do Termo de Mariana, Antonio Carlos Monteiro de Moura, decidisse favoravelmente à libertação dos filhos e netos de Antônio Francisco do Espírito Santo, ficando o réu condenado a pagar os custos do processo.

Porém, o réu recorreu da sentença e, três meses depois, tem a causa decidida a seu favor. O juiz, desta vez Antonio Euleno de Mello e Sousa, não teve dúvidas de que a regra do direito que estabelecia que "o parto segue o ventre" beneficiava ao réu, Antônio Moutinho Esteves. Do processo consta, ainda, o pedido de que toda a documentação fosse reproduzida para que Antonio do Espírito Santo recorresse ao Tribunal de Relação do Rio de Janeiro. ${ }^{41}$

A história de Francisco do Espírito Santo, se não foi recorrente no contexto da sociedade escravista da província mineira, também não parece ter sido um caso isolado. Ao prestar seu depoimento na ação de liberdade movida por Espírito Santo, o capitão José Valente de Souza, de 66 anos, afirmou que o réu, Moutinho Esteves, tinha conhecimento de um casamento que se efetuou na Barra do Bacalhau, também Termo de Mariana, em que o marido, um liberto, se comprometera a servir por dez anos em troca da alforria de sua esposa. Cumpridos cinco anos, ele se retirara com a mulher para Mariana, onde teria movido um "pequeno litígio" com base no argumento de que seus cinco anos de serviços prestados, somados aos cinco anos trabalhados por sua esposa para o mesmo proprietário, perfaziam os dez anos ajustados. O resultado, ainda segundo o testemunho do capitão, teria sido favorável ao casal.

leis que procuravam regulamentar as relações de trabalho e os contratos estabelecidos com imigrantes e que serviam de parâmetro para os trabalhadores livres nacionais. Ainda em 1837, a lei n.108 estabelecia as regras para os contratos com imigrantes, os trabalhadores livres nacionais continuariam a reger seus contratos pela lei de 13 de setembro de 1830. A Lei do Ventre Livre, 1871; a Lei de Locação de Serviços de 1879 e a Lei dos Sexagenários, 1885, sob a ótica da formação do mercado de trabalho, continham elementos que objetivavam fixar e controlar a mão-de-obra. A manutenção de escravos em condição de "libertandos" sob a tutela governamental, como no caso das leis de 1871 e 1885, previa a educação desses novos trabalhadores, possibilitando não apenas a reorganização da lavoura diante das mudanças nas relações de trabalho, como a incorporação de valores relacionados à ética do trabalho. Fixar e controlar o ex-escravo através não mais da coerção física, mas, dos laços estabelecidos foi a estratégia utilizada por muitos senhores paulistas a partir principalmente de 1887. Sobre o assunto, ver CASTRO, Hebe Maria Mattos de. Das cores do silêncio: os significados da liberdade no sudeste escravista - Brasil século XIX. Rio de Janeiro: Nova Fronteira, 1995.

41 Tentamos, sem sucesso, localizar no Arquivo Nacional a ação movida por Antônio do Espírito Santo contra Moutinho Esteves. Sabemos apenas que "O coronel Francisco de Paula Ramos Horta, advogado que defendeu a liberdade da família na justiça de Mariana, transferiu todos os poderes que lhe foram outorgados por meio de procuração ao 'llustríssimo Senhor Advogado Antônio Pereira Rebouças'". DIAS, Silvania de Oliveira. As ações de liberdade de escravos na justiça de Mariana, 1850-1888. Mariana: UFOP, 2010, p.72. (História, Dissertação de mestrado). 


\section{Breves considerações finais}

As histórias e casos reconstituídos aqui recobrem um período longo de tempo e apresentam um mosaico de situações que, no mínimo, dificultam que se identifiquem, como um grupo comum, índios, recrutas, galés, africanos livres, agregados e forros. Porém, um elemento parece unificar as experiências relatadas: a precariedade e instabilidade da liberdade vivenciada por esses contingentes da população brasileira oitocentista. Talvez eles se apresentem como a contra face daquele grupo de homens livres, também pobres em sua origem, muitas vezes egressos do cativeiro, que alcançaram acumular pecúlio e tornarem-se proprietários de escravos. Em ambos os casos, registra-se a centralidade da instituição da escravidão na definição das relações sociais no Brasil oitocentista. 